\title{
Potential Application of Propolis Extracts to Control the Growth of Stemphylium vesicarium in "Rocha" Pear
}

\author{
Marcella Loebler ${ }^{1,2}$, Claudia Sánchez ${ }^{2,3, *}$, Elisabete Muchagato Maurício ${ }^{4}$, Eugénio Diogo ${ }^{2,5}$, \\ Mário Santos ${ }^{2}$, Paula Vasilenko ${ }^{2}$, Ana Sofia Cruz ${ }^{1}$, Benilde Mendes ${ }^{1}$, Margarida Gonçalves ${ }^{1}$ (D) \\ and Maria Paula Duarte ${ }^{1, *}$ \\ 1 DCTB/MEtRICs, Faculdade de Ciências e Tecnologia, Universidade NOVA de Lisboa, Campus de Caparica, \\ 2829-516 Caparica, Portugal; ml.nascimento@campus.fct.unl.pt (M.L.); as.cruz@campus.fct.unl.pt (A.S.C.); \\ bm@fct.unl.pt (B.M.); mmpg@fct.unl.pt (M.G.) \\ 2 Instituto Nacional de Investigação Agrária e Veterinária (INIAV) Oeiras, 2780-157 Portugal; \\ eugenio.diogo@iniav.pt (E.D.); mario.santos@iniav.pt (M.S.); paula.vasilenko@iniav.pt (P.V.) \\ 3 Instituto Nacional de Investigação Agrária e Veterinária (INIAV), Estação Nacional de Fruticultura de Vieira \\ Natividade, 2460-059 Alcobaça, Portugal \\ 4 CBIOS/DREAMS/Universidade Lusófona, Campo Grande, 376, 1749-024 Lisboa, Portugal; \\ p278@ulusofona.pt \\ 5 University of Lisboa, Faculty of Sciences, BioISI-Biosystems \& Integrative Sciences Institute Campo Grande, \\ C8 bdg, 1749-016 Lisboa, Portugal \\ * $\quad$ Correspondence: claudia.sanchez@iniav.pt (C.S.); mpcd@fct.unl.pt (M.P.D.); Tel.: +351-21-2948543 (M.P.D.)
}

Received: 14 February 2020; Accepted: 9 March 2020; Published: 14 March 2020

Abstract: Stemphylium vesicarium (Wallr.) E. G. Simmons is the pathogen responsible of brown spot disease in pear and has become one of the main concerns for European pear producers. In Portugal, $S$. vesicarium is responsible for significant yield reduction and economic losses in "Rocha" pear (Pyrus communis L. cv Rocha) production. Considering the antimicrobial potential of propolis, the high incidence of brown spot in pears and the emergence of fungicides resistance in S. vesicarium, this study aimed to evaluate the potential of Portuguese propolis as an alternative strategy to control brown spot disease in "Rocha" pear. In vitro assays showed that propolis extracts were able to inhibit up to $90 \%$ the $S$. vesicarium mycelial growth. In vivo assays in artificially wounded and inoculated "Rocha" pears showed that, compared to the control, the disease incidence decreased up to $25 \%$ and the lesions diameter up to $57 \%$, in fruits treated with propolis. Moreover, propolis seems to be more efficient in reducing the disease incidence when applied after pathogen inoculation (curative assay) than when applied before pathogen inoculation (prophylactic assay). Thus, the results suggest that propolis extracts have potential to be applied as part of an integrated approach for the control of brown spot of pear.

Keywords: Portuguese propolis; brown spot disease; pear fungal disease; biological control; antifungal activity

\section{Introduction}

"Rocha" pear (Pyrus communis L. cv Rocha) is an exclusively Portuguese pear variety, whose production is mainly concentrated in the west region of the country and has major economic relevance (average annual fruit production of about 173,000 tons, data from Associação Nacional de Produtores de Pera Rocha), accounting for $95 \%$ of the Portuguese pear production. Fungal infection is a constant threat to fruit production. Particularly, in what concerns "Rocha" pear production, infection 
by Stemphylium vesicarium (Wallr.) E.G. Simmons, the causal agent of brown spot disease, has become one of the main concerns. In fact, the incidence of this disease in "Rocha" pear has been increasing in recent years causing significant yield reduction and important economic losses. In 2015, brown spot disease was responsible for losses of $25 \%$ of "Rocha" pear production [1].

Brown spot disease was reported in several European pear-producing countries like Spain, Italy, France, the Netherlands, Belgium, and Portugal [2]. The disease symptoms consist of necrotic lesions on fruits, leaves, and shoots. Fruit lesions gradually expand and deepen in round-shaped brown areas that can decay [3]. Infected fruits lose their commercial value and severe outbreaks can lead to fruit abscission prior to harvest [4].

Brown spot is a complex disease because of the biology and ecological ability of the causative agent [5]. S. vesicarium can colonize pear leaf and dead tissues of herbaceous plants on the ground [6]. It is known that the incidence of brown spot disease is higher in pear orchards with a lawn of herbaceous plants than in bare soils [3]. With regard to chemical treatments, several resistant strains have been detected in S. vesicarium. The emergence of these resistant strains has been connected with serious failures in field control [7]. Therefore, to control brown spot disease an integrated approach should be used, including preventive measures to reduce the presence of inoculum in the orchard, complemented with preventive chemical and/or biological control $[1,8]$. The severity of brown spot of pears allied with its high incidence and difficulty in treatment, motivate the search for new control methods.

Propolis is a resinous material produced by bees (Apis mellifera) by combining plant exudates, with the bees' salivary enzymes, waxes, and pollen. Honey bees use propolis in their hives to repair fissures and as a surface cover, hardener, and preservative. The composition and characteristics of propolis is correlated to the specificity of the flora at the collection site, as well as factors such as seasonality and type of collector used in apiary $[9,10]$. More than 300 constituents have already been identified in propolis from different origins. Among these constituents, there are minerals and organic compounds such as phenolic acids or their esters, flavonoids, aldehydes, terpenes, alcohols, and fatty acids [11-14].

Propolis has been used in alternative medicine for a long time, as an antifungal, antibacterial, antiviral, or anti-inflammatory agent [14-16]. These biological activities are attributed to flavonoids and other phenolic compounds, as well as to diterpenes which have been identified in propolis, and whose antioxidant and/or antimicrobial activities have been widely described $[15,17,18]$.

Several studies reported the effectiveness of various propolis extracts to inhibit the in vitro growth of different phytopathogenic fungi, including Colletotrichum gloeosporioides [17], Penicillium italicum [19], Botryodiplodia theobromae [17], P. digitatum [19-21], P. expansum [22], Colletotrichum spp. [23], or Botrytis cinerea $[23,24]$. Moreover, propolis extracts were able to efficiently reduce $P$. expansum growth in vivo, in artificially wounded pears inoculated with the pathogen [22], as well P. digitatum and P. italicum in vivo growth in wound-inoculated and naturally infected citrus fruits, respectively, without having a negative impact on the overall fruit quality [19].

Considering the antifungal potential of propolis extracts, the high incidence of brown spot disease in "Rocha" pear, the economic importance of this culture in Portugal, and the proliferation of fungicides resistance in S. vesicarium, this study aims to evaluate the potential of Portuguese propolis extracts as an alternative strategy to control brown spot disease caused by this phytopathogenic fungus in "Rocha" pear.

\section{Materials and Methods}

\subsection{Reagents}

2,2-diphenyl-1-picrylhydrazyl (DPPH), Trolox, and 2,4,6-tris(2-pyridyl)-s-triazine (TPTZ) were from Sigma-Aldrich (St. Louis, MO, USA). Ethanol absolute, iron(II) sulfate heptahydrate and methanol were from Riedel-de Haën (Seelze, Germany). Acetic acid, hydrochloric acid, and sodium acetate trihydrate were from Panreac (Barcelona, Spain). Gallic acid, iron(III) chloride hexahydrate, sodium carbonate, and Folin-Ciocalteu reagent were from Merck (Darmstadt, Germany). Potato dextrose 
agar (PDA) was from Biokar Diagnostics (Allonne, France). Tween- 80 was from AppliChem GmbH (Darmstadt, Germany). The water used was purified using a Milli-Q water purification system (Millipore, Bedford, MA, USA) and all chemicals were of analytical reagent grade.

\subsection{Propolis Samples and Extracts Preparation}

Crude Portuguese propolis from different locations was supplied by different producers and kept stored at $-20^{\circ} \mathrm{C}$ until further usage. In the present study four different extracts (E1, E2, E3, and E4) were used: E1 and E2 were prepared using propolis from the central coast of Portugal and E3 and $\mathrm{E} 4$ were prepared using a mixture of propolis from the central coast and from the northern region of Portugal.

E1 and E2 were obtained by maceration in $96 \%(\mathrm{v} / \mathrm{v})$ ethanol (E1) or $70 \%(\mathrm{v} / \mathrm{v})$ ethanol (E2) in the dark for 5 days at room temperature. The insoluble residue was removed by filtration and the filtrated solutions were stored at $-20^{\circ} \mathrm{C}$ and, thereafter, filtrated one more time.

E3 and E4 were prepared according to the procedure described by Bankova et al. [25] with slight modifications. Briefly, $96 \%$ ethanol (E3) or 70\% ethanol (E4) was added to the propolis and the mixture was sonicated for $20 \mathrm{~min}$ in an ultrasonic bath at $20^{\circ} \mathrm{C}$ and kept in the dark for $24 \mathrm{~h}$ at room temperature (20 to $22{ }^{\circ} \mathrm{C}$ ). The resulting suspension was filtered and the procedure was repeated with the part trapped in the filter. Finally, the filtrated solutions were combined, stored at $-20^{\circ} \mathrm{C}$, and thereafter filtrated once more.

The concentration of all the extracts was determined gravimetrically, after evaporating $2.0 \mathrm{~mL}$ of each extract to dryness [25]. Subsequently, the concentration was adjusted with $96 \%$ (E1 and E3) or $70 \%$ (E2 and E4) ethanol so that all extracts had a final concentration of $30.0 \mathrm{mg} / \mathrm{mL}$.

\subsection{Propolis Extracts Characterization}

Ethanolic propolis extracts were characterized in terms of total phenolic content (Folin-Ciocalteu assay), antiradical activity (DPPH assay), and reducing activity (FRAP assay).

\subsubsection{Determination of Propolis Total Phenolic Content}

Total phenolic compounds were estimated as gallic acid equivalents (GAE) according to the procedure described by Koşar et al. [26]. Briefly water $(6.0 \mathrm{~mL})$, sample $(100 \mu \mathrm{L})$ and undiluted Folin-Ciocalteu reagent $(500 \mu \mathrm{L})$ were mixed in a $10.0 \mathrm{~mL}$ volumetric flask. After $1 \mathrm{~min}, 1.5 \mathrm{~mL}$ of $20 \%(\mathrm{w} / \mathrm{v}) \mathrm{Na}_{2} \mathrm{CO}_{3}$ was added and the volume was made up to $10.0 \mathrm{~mL}$ with water. After $2 \mathrm{~h}$ incubation at room temperature $\left(20\right.$ to $\left.22{ }^{\circ} \mathrm{C}\right)$ and in the dark, the absorbance was read using a UV/VIS spectrophotometer (SPEKOL 1500, Analytik Jena, Germany) at $765 \mathrm{~nm}$ and compared to a gallic acid calibration curve. Results were expressed as milligram gallic acid equivalents (GAE) per gram of dry extract.

\subsubsection{Ferric Reducing Antioxidant Power (FRAP) Assay}

The FRAP assay was performed following the procedure described by Lima et al. [27]. Briefly, $3.0 \mathrm{~mL}$ of freshly prepared and pre-warmed at $37{ }^{\circ} \mathrm{C}$ FRAP reagent $(20 \mathrm{~mL}$ of $10 \mathrm{mM}$ TPTZ solution in $40 \mathrm{mM} \mathrm{HCl}$ and $20 \mathrm{~mL}$ of $20 \mathrm{mM}$ ferric chloride in $200 \mathrm{~mL}$ of $0.25 \mathrm{M}$ sodium acetate buffer, pH 3.6) and $400 \mu \mathrm{L}$ of each sample were mixed, and the absorbance of the resulting mixture was measured using a UV/VIS spectrophotometer (SPEKOL 1500, Analytik Jena, Germany) at $593 \mathrm{~nm}$, after 4 min incubation at $37^{\circ} \mathrm{C}$. A calibration curve of ferrous sulphate was used and results were expressed as mmol $\mathrm{Fe}^{2+}$ equivalents per gram of dry extract.

\subsubsection{DPPH Radical-Scavenging Assay}

The DPPH assay was performed based on the methodology described by Kedare and Singh [28]. Thus, $500 \mu \mathrm{L}$ of each sample was mixed with $4.0 \mathrm{~mL}$ of freshly prepared DPPH solution $(45 \mathrm{mg} / \mathrm{L}$ 
in methanol) and the absorbance was read using a UV/VIS spectrophotometer (SPEKOL 1500, Analytik Jena, Germany) at $517 \mathrm{~nm}$ after $30 \mathrm{~min}$ incubation in the dark. Trolox was used as reference. Results were expressed as mg trolox equivalents (TE) per gram of dry extract.

\subsection{In Vitro Antifungal Activity of Propolis Extracts Against Stemphylum vesicarium}

Stemphylum vesicarium was from the collection of Instituto Nacional de Investigação Agrária e Veterinária (MEAN Nº 1163, Micoteca da Estação Agronómica Nacional, INIAV, Oeiras, Portugal). This strain was isolated from infected tissues of "Rocha" pear fruits with symptoms of brown spot disease. The in vitro antifungal activity was performed as previously described [22]. Briefly, $1.0 \mathrm{~mL}$ of appropriately diluted propolis extracts were mixed with $14.0 \mathrm{~mL}$ of PDA medium and distributed into Petri dishes. The extracts dilutions were carried out in order to reach the following concentrations in the Petri dishes: $0.2,0.5$, and $1.0 \mathrm{mg}$ dry extract $/ \mathrm{mL}$. As extracts were diluted in ethanol, solutions of $70 \%$ (E2 and E4) or $96 \%$ (E1 and E3) ethanol were used as control. After complete solidification, mycelial discs (6 mm diameter) from the actively growing margin of a 7-day-old pure culture of S. vesicarium were applied at the center of PDA plates $(90 \mathrm{~mm}$ in diameter) (three Petri dishes for each propolis concentration) and incubated at $25 \pm 2{ }^{\circ} \mathrm{C}$, in the dark, for 14 days. For each Petri dish, the mycelial diameter was calculated as the average of two perpendicular diameter measurements with a ruler $( \pm 0.5 \mathrm{~mm})$. Measurements were performed every three days, for 14 days. The antifungal effect was evaluated using a random design with three replications.

\subsection{In Vivo Antifungal Activity of Propolis Extracts Against Stemphylum vesicarium}

S. vesicarium was cultured in PDA medium and incubated for 7 to 10 days at $25{ }^{\circ} \mathrm{C}$ under fluorescent light (12 h day length). Subsequently, spores were harvested in $10 \mathrm{~mL}$ of distilled water supplemented with Tween $80(0.01 \%, \mathrm{v} / \mathrm{v})$ and the concentration was adjusted with distilled water supplemented with Tween $80(0.01 \%, \mathrm{v} / \mathrm{v})$ to $10^{4}$ spores $/ \mathrm{mL}$, using a Neubauer's chamber. To evaluate the in vivo antifungal activity of propolis, "Rocha" pears cultivated in Alcobaça (western region of Portugal) and harvested at the stage of commercial maturity, were surface disinfected with $0.5 \%(\mathrm{v} / \mathrm{v})$ sodium hypochlorite, rinsed with tap water for $5 \mathrm{~min}$ and air-dried. Fruits were artificially wounded twice (each wound $15 \mathrm{~mm}$ distant from the equatorial region) to a depth of $4 \mathrm{~mm}$ and a diameter of $4 \mathrm{~mm}[28]$.

Subsequently, for the curative assay 40 wounds were inoculated with $20 \mu \mathrm{L}$ of the spore suspension previously described. After one hour, $20 \mu \mathrm{L}$ of two different concentrations of propolis extract $\mathrm{E} 4$ $(30.0 \mathrm{mg} / \mathrm{mL}$ or $6.0 \mathrm{mg} / \mathrm{mL})$ were applied to each of the wounds. As E4 was diluted in ethanol $(70 \%, \mathrm{v} / \mathrm{v})$, ethanol $(70 \%, \mathrm{v} / \mathrm{v})$ was used as control. In the prophylactic assay, 40 wounds were treated with $20 \mu \mathrm{L}$ of $\mathrm{E} 4(30.0 \mathrm{mg} / \mathrm{mL})$ or $20 \mu \mathrm{L}$ of $70 \%$ ethanol (control assay) one-hour prior the inoculation with $20 \mu \mathrm{L}$ of the spore suspension. In both assays (curative and prophylactic) the pears were incubated in boxes, protected with plastic bags, at $20-22{ }^{\circ} \mathrm{C}$ and $70-80 \%$ relative humidity $(\mathrm{RH})$ for 14 days. The number of infected wounds and the diameter of the lesions were measured daily. The wound diameter was calculated as the average of two perpendicular diameter measurements with a transparent ruler $( \pm 0.5 \mathrm{~mm})$. The antifungal capacity was assessed by the percentage of infected wounds (disease incidence) and by the reduction of lesion diameter over time (treatment efficacy), relative to the control assay. The assays were conducted in a completely randomized design and repeated twice.

In order to evaluate the potential cytotoxic effect of propolis extract on pear pulp an assay in which the wounds were treated only with undiluted propolis extract was also performed. In this assay the pears were also kept at $20-22{ }^{\circ} \mathrm{C}$ and $70-80 \%$ RH for 14 days.

\subsection{Statistical Analysis}

After verifying the assumption of normality and variance homogeneity (Cochran, Hartley and Bartlett tests), one-way analysis of variance (ANOVA) followed by Tukey's test were used to identify 
significant differences between samples and/or treatments. All statistical analyses were performed at 0.05 level of probability with the software STATISTICA ${ }^{\text {TM }} 7.0$ (StatSoft, Tulsa, OK, USA).

\section{Results and Discussion}

\subsection{Propolis Extracts Characterization}

The biological activity/properties of propolis are related to its chemical composition, namely the presence and concentration of specific phenolic compounds with antimicrobial and antioxidant properties [22,29]. The concentration of those compounds in propolis extracts could vary because of many factors, such as the production region, period of harvesting, methodological differences in extract preparations, solvent used, time and temperature of extraction [13,29-32]. For instance, Jug et al. [29] showed that the antimicrobial action of aqueous propolis extracts against different microorganisms was inferior compared to corresponding ethanolic propolis extracts. According to the same authors, this difference is a consequence of the low water solubility of most compounds with antimicrobial activity.

In a preliminary approach, the total phenolic content and the antioxidant activity of 34 propolis extracts, obtained according to different methodologies and using samples of propolis from different Portuguese regions, were determined (data not shown). Among these 34 extracts, four (E1, E2, E3 and E4) were selected for this work, because of their high phenolic content and antioxidant activity (DPPH and FRAP) (Table 1).

Table 1. Propolis extracts characterization.

\begin{tabular}{cccc}
\hline \multirow{2}{*}{ Propolis Extract } & Phenolic Compounds & DPPH & FRAP \\
\cline { 2 - 4 } & (mg GAE/g Dry Extract) $^{\text {(mg TE/g Dry Extract) }}$ & $\mathbf{( m m o l ~ F e ~}^{\mathbf{2 +}} \mathbf{/ g}$ Dry Extract) \\
\hline E1 & $275.0 \pm 7.1^{\mathrm{b}}$ & $318.3 \pm 3.5^{\mathrm{a}}$ & $3.7^{\mathrm{a}} \pm 0.1^{\mathrm{c}}$ \\
E2 & $300.0 \pm 3.8^{\mathrm{a}}$ & $313.5 \pm 3.1^{\mathrm{a}}$ & $4.6^{\mathrm{a}} \pm 0.1^{\mathrm{b}}$ \\
E3 & $298.0 \pm 5.0^{\mathrm{a}}$ & $281.5 \pm 2.4^{\mathrm{b}}$ & $4.1 \pm 0.1^{\mathrm{b}}$ \\
E4 & $313.7 \pm 12.5^{\mathrm{a}}$ & $258.1 \pm 1.8^{\mathrm{c}}$ & $4.0 \pm 0.2^{\mathrm{b}}$ \\
\hline
\end{tabular}

In each column, different letters denote significant differences $(p<0.05)$.

The four ethanolic extracts of Portuguese propolis showed a high total phenolic content (between 275-314 mg GAE/g dry extract) and a significant anti-radical activity according to the DPPH test (258-318 mg TE/g dry extract), and ferric reduction antioxidant power (3.7-4.6 $\mathrm{mmol} \mathrm{Fe}^{2+} / \mathrm{g}$ dry extract). It is difficult to compare the obtained results, concerning total phenolic content and the antioxidant activities, with those obtained by others because of discrepancies in the methods used for quantification, compounds used as references, and the units used to express the results ( $\mathrm{g}$ raw propolis, $\mathrm{mL}$ of extract, g dry extract, etc.,). Nevertheless, the total phenolic contents observed were in line with other studies with propolis samples from central coast and north-eastern regions of Portugal [10,30].

Significant differences were observed among the total phenolic content and antioxidant activity of the four extracts analyzed. Thus, E1 showed a total phenolic content and a reducing activity significantly lower than E2, E3, and E4. On the other hand, E1 presented a DPPH radical-scavenging capacity significantly higher than E3 and E4. The differences observed among the four propolis extracts can result from their specific composition in phenolic compounds. When analyzing different samples of propolis, da Silva et al. [33] showed that the total phenolic content is not directly correlated with the biological activity of the extracts. Other authors have reported that the antioxidant and/or antimicrobial properties of propolis extracts correlates not only with their concentration of total polyphenols, but also with the presence of some individual components, such as pinocembrin [34]. The analysis of 40 propolis samples, collected from six different geographical origins in Portugal, showed that most of them had a similar phenolic profile, but with differences in concentrations, presenting the samples from north and central coast the highest phenolic concentration [35]. In general flavonoids are more abundant 
than phenolic acids and esters, being pinocembrin, chrysin, pinobanksin-3-O-acetate, and galangin the major compounds [35].

\subsection{In Vitro Antifungal Activity of Propolis Extracts Against Stemphylium vesicarium}

All propolis extracts assayed were able to inhibit in vitro $S$. vesicarium mycelial growth in all the concentrations tested (Figure 1). For E2 the inhibition of mycelial growth increased significantly with the increase of propolis concentration in the culture medium (Figures 1 and 2). However, for the other propolis extracts (E1, E3, and E4) there were no significant differences in the percentage of inhibition of mycelial growth between the two highest concentrations assayed ( 0.5 and $1.0 \mathrm{mg} / \mathrm{mL}$ ) (Figures 1 and 2). After 14 days of incubation at $25^{\circ} \mathrm{C}$, and for the highest concentration tested $(1.0 \mathrm{mg} / \mathrm{mL})$, extracts E3 and $\mathrm{E} 4$ presented a percentage of mycelial growth inhibition ( $90 \%)$ significantly higher than extracts E1 ( $78 \%)$ and E2 ( $74 \%)$ (Figure 2$)$. Thus, results showed that, among the extracts assayed, extracts containing northern propolis (E3 and E4) and/or prepared by the ultrasound-assisted extraction were more efficient in inhibiting $S$. vesicarium growth in vitro.

As mentioned above, the biological activity of propolis derive from the plants available in its production area and consequently, variations in the antimicrobial activity may occur according to the propolis origin. Therefore, the results obtained suggest that propolis from the northern region of Portugal could be a good source of compounds with antifungal properties. Moreover, as biological activities are also related to the extraction method, the results obtained may also be associated to the ultrasound-assisted extraction method used to prepare E3 and E4. Ultrasounds enlarge the pores of the cells and the fragmentation of the extracted material, increasing their contact with the fresh solvent and enhancing the extraction yields [36]. While some authors reported that ultrasound-assisted extraction was more efficient than maceration in extracting propolis antimicrobial compounds [37], others have reported that the antibacterial activity of extracts obtained by ultrasound-assisted extraction was similar to that of extracts obtained by maceration [36].

The activity of propolis against $S$. vesicarium is in line with the literature data. In fact, several authors reported that propolis has a wide antimicrobial range of activity, being effective against different bacteria, yeasts, protozoa, and filamentous fungi [31,38-41], including phytopathogenic fungi $[17,19-22,42]$.

The mechanism of microbial growth inhibition exerted by propolis has not yet been fully elucidated. Several studies point out that the phenolic compounds from propolis may interfere with the integrity of the cell membrane, thus making cell survival unviable. This interference may occur by destabilization of cytoplasmic membrane with alteration of its potential and permeability [32,43]. The inhibition of nucleic acid synthesis (DNA and RNA), proteins and lipids, as well as the inhibition of several enzymes, has been other mechanisms of antimicrobial activity attributed to phenolic compounds [43]. Particularly, in the case of fungi, bioactive compounds from propolis may change cell surface hydrophobicity and charge, eventually triggering the leak of cytoplasmic content [44]. Several of these compounds can also interfere with cytoplasmatic membrane and cell wall integrity, by interfering with ergosterol or $1,3-\beta$-glucan synthesis or through chitin-binding ability [44].

Yang et al. [19] reported that Chinese propolis extracts present a strong inhibitory activity against Penicillium digitatum and Penicillium italicum. The same authors later identified pinocembrine, pinobanksin, chrysin, and galangin as the compounds probably responsible for these antifungal activities [42]. Pinocembrin isolated from propolis, showed strong antifungal effects against $P$. italicum by interfering with energy homeostasis, causing disruption of cell membranes and metabolic disorders [45]. These flavonoids (pinocembrin, chrysin, pinobanksin and galangin) are highly abundant in Portuguese propolis $[22,35]$ and, thus, may be responsible for the detected antifungal activity. 

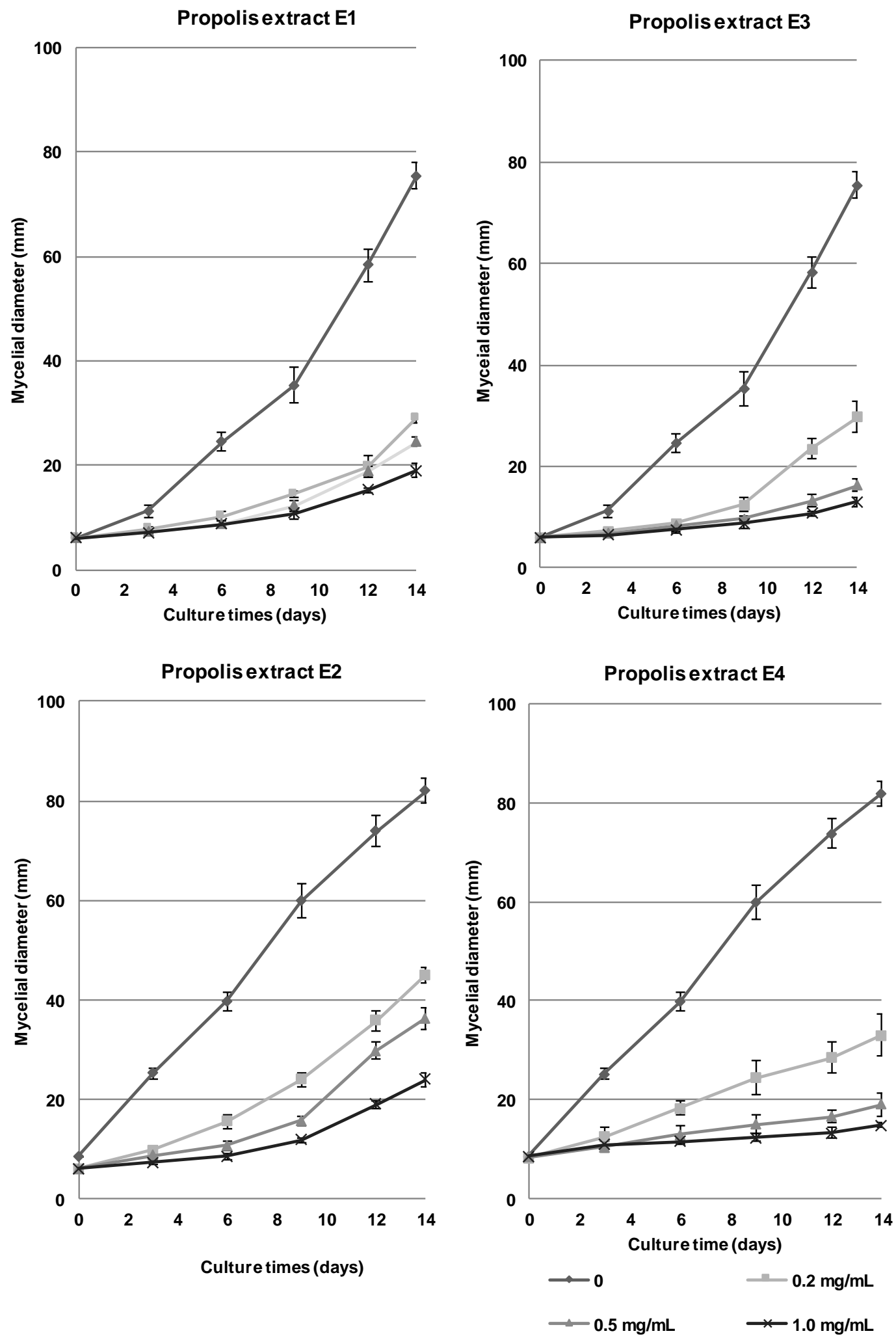

Figure 1. In vitro $S$. vesicarium mycelial growth in potato dextrose agar (PDA) medium without propolis $(0 \mathrm{mg} / \mathrm{mL})$ and with different concentrations $(0.2,0.5$, and $1.0 \mathrm{mg} / \mathrm{mL})$ of propolis extracts $(\mathrm{E} 1, \mathrm{E} 2$, $\mathrm{E} 3$, and E4), after 14 days of incubation at $25^{\circ} \mathrm{C}$. Data presented are means \pm standard deviation of three replicates. 


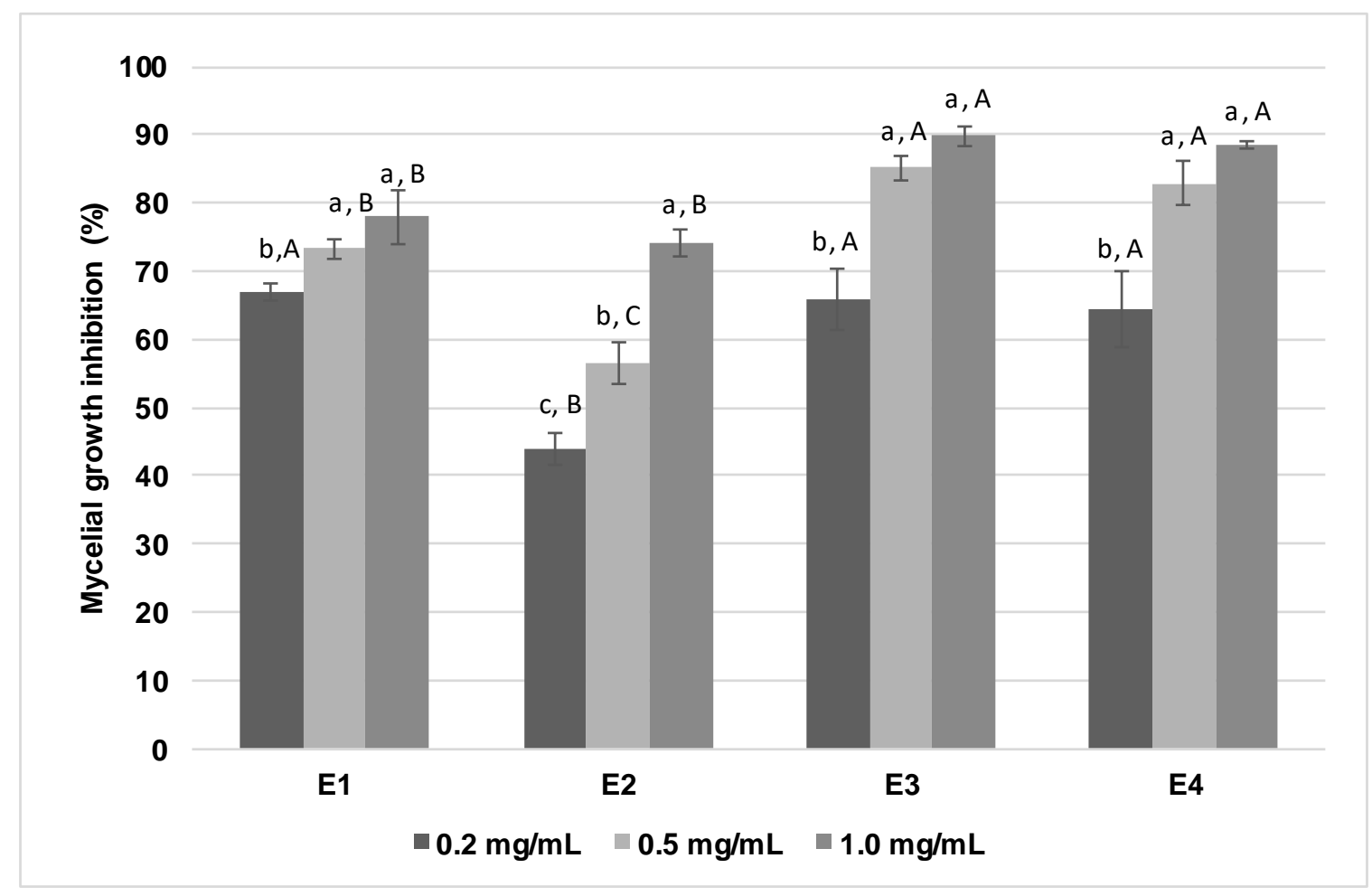

Figure 2. Percentage of Stemphylium vesicarium mycelial growth inhibition in the presence of different concentrations $(0.2,0.5$, and $1.0 \mathrm{mg} / \mathrm{mL})$ of the four propolis extracts $(\mathrm{E} 1, \mathrm{E} 2, \mathrm{E} 3$, and E4) after 14 days of incubation at $25^{\circ} \mathrm{C}$. Results are presented as means \pm standard deviation of three replicates. Different lower-case letters denote significant differences among the percentage of mycelial growth inhibition obtained with different concentration of each propolis extract $(p<0.05)$. Different upper-case letters denote significant differences among the percentage of mycelial growth inhibition obtained with the same concentration of the different propolis extracts $(p<0.05)$.

\subsection{In vivo Antifungal Activity of Propolis Extracts Against Stemphylium vesicarium}

The ability of propolis to control S. vesicarium was also assayed in vivo in "Rocha" pears, by assessing the decrease of the number of infected wounds (disease incidence) and the reduction of lesions diameter over time (treatment efficacy), in relation to control, in curative and prophylactic assays. Propolis extract E4 was selected for the in vivo assay because of its high total phenolic content and in vitro inhibitory activity against $S$. vesicarium. Aiming to evaluate a potential cytotoxic effect of propolis on pear pulp, a control in which the wounds were treated only with undiluted propolis extract (without pathogen inoculation) was performed. No symptoms of apparent toxicity were observed in the pear tissues, the wounds were healed, and no browning was observed.

The curative assay was performed with two different concentrations of E4, namely $30.0 \mathrm{mg} / \mathrm{mL}$ (undiluted extract) and $6.0 \mathrm{mg} / \mathrm{mL}$ (1:5 dilution of initial extract). After 14 days of incubation the disease incidence decreased significantly in propolis-treated fruits in a dose-dependent manner (Figure 3). Comparing to the control, the disease incidence decreased $25.0 \%$ in fruits treated with the highest extract concentration $(30.0 \mathrm{mg} / \mathrm{mL})$ and $15.0 \%$ in fruits treated with the lowest extract concentration $(6.0 \mathrm{mg} / \mathrm{mL})$.

The extract concentration with the higher inhibitory effect in the curative assay $(30.0 \mathrm{mg} / \mathrm{mL})$ was selected for the prophylactic assay. In this case, the disease incidence also decreased in propolis-treated fruits, but this reduction was less pronounced (15.0\%) (Figure 3). 


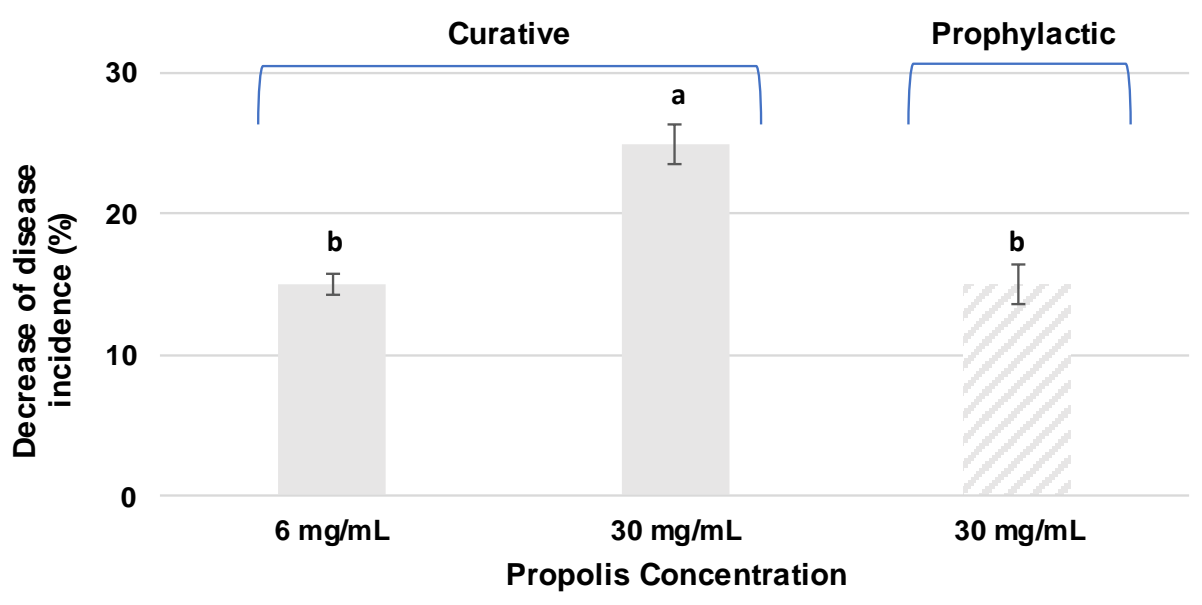

Figure 3. Decrease of the disease incidence relative to control after 14 days of incubation at $20{ }^{\circ} \mathrm{C}$ in the curative (left) and prophylactic (right) assays. Results are presented as means \pm standard deviation of two replicates Different letters denote significant differences among the decrease of disease incidence relative to control $(p<0.05)$.

In agreement with the results obtained in the in vitro assay, propolis was also able to reduce the in vivo growth of $S$. vesicarium since, compared to the control, lesion diameter decreased significantly in propolis-treated fruits in a dose-dependent manner (Figure 4). In the curative assay, the lesion diameter decreased $56.6 \%$ in fruits treated with the highest extract concentration $(30.0 \mathrm{mg} / \mathrm{mL})$ and $34.2 \%$ in fruits treated with the lowest extract concentration $(6.0 \mathrm{mg} / \mathrm{mL})$. In the prophylactic assay, the lesion diameter decreased $55.9 \%$ in propolis-treated fruits. Accordingly, there were no significant differences in the efficacy of prophylactic and curative treatments (Figure 4).

Thus, under the conditions of the present study, it seems that in vivo propolis is effective in reducing both the incidence of infection, especially if applied curatively, and the disease severity.

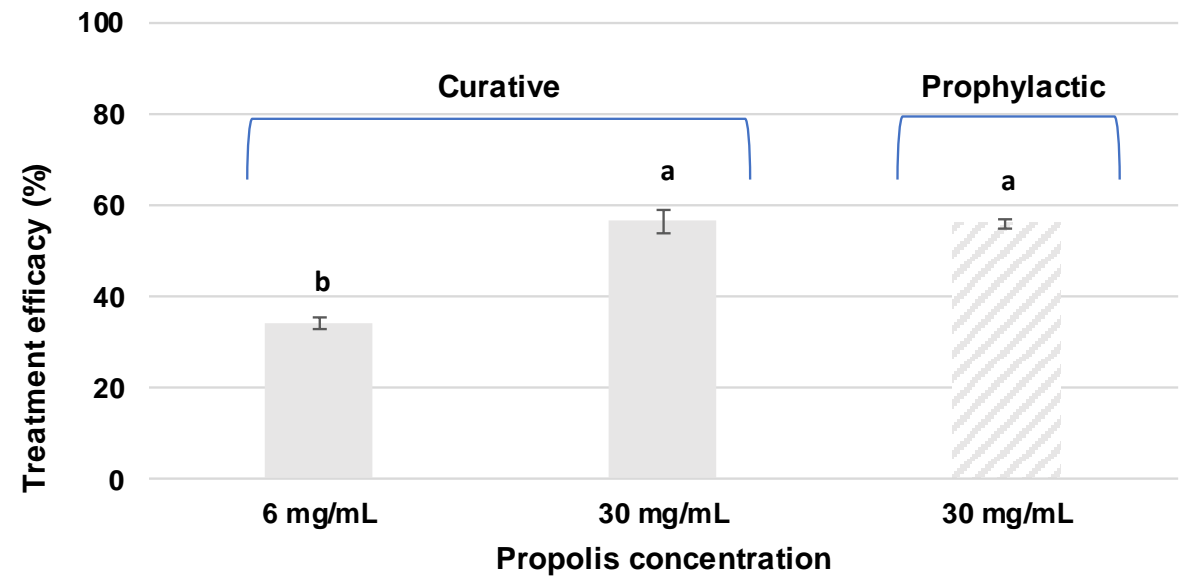

Figure 4. Reduction of lesions diameter (treatment efficacy) relative to control after 14 days of incubation at $20^{\circ} \mathrm{C}$ in the curative (left) and prophylactic (right) assays Results are presented as means \pm standard deviation of two replicates. Different letters denote significant differences among treatments efficacy $(p<0.05)$.

As mentioned above, fungicides vary in efficacy and with disease pressure [2]. Moreover, repeated use of some types of fungicides has been restricted by the emergence of fungicide-resistant strains [46]. Thus, there is a need for the search of new strategies to control S. vesicarium.

To the best of authors' knowledge, so far, no studies focused on the use of propolis extracts to control S. vesicarium growth in "Rocha" pear. However, several in vivo studies describe the activity of 
propolis extracts against phytopathogenic fungi in different fruits and plants. Sánchez et al. [22] studied the in vivo antifungal effect of propolis extracts against $P$. expansum and concluded that propolis was effective in controlling the growth of this pathogen in "Rocha" pear. In that study, after 4 days of incubation, a reduction of the lesion diameter and of disease incidence of about $40 \%$ was observed in fruits treated with propolis extract [22]. Propolis ethanolic extracts also demonstrated in vivo efficacy in controlling the disease caused by P. digitatum in oranges, reducing its incidence by up to $\sim 78 \%$ [47]. When applied to coffee plant seedling leaves, ethanolic propolis extracts were able to reduce the incidence and severity of Cercospora coffeicola infection, in a dose-dependent manner [48]. Propolis extract, combined with cinnamon oil incorporated with gum arabic as the base coating, proves to be effective for postharvest anthracnose (Colletotrichum capsici) control in chilli [49]. Other in vivo assays with two varieties of apples, namely Dorestt Golden and Red delicious, revealed that propolis extract inhibited the fungal growth on apple fruits compared with control, being effective in inhibiting Alternaria alternata, Aspergillus niger, Fusarium sp., and P. expansum [50].

On the other hand, plant extracts [51], synthetic antimicrobial peptides [52], or the use of antagonists $[3,53]$ are described as promising strategies to control S. vesicarium. Abdel-Hafez et al. [51] showed the effectiveness of plant extracts, particularly of Azadirachta indica and Datura stramonium, to control S. vesicarium blight disease of onion (Allium cepa L.) under greenhouse conditions [51]. These extracts proved to be very effective at controlling the disease, with a disease reduction percentage that reached up to $\sim 90 \%$ before and after S. vesicarium inoculation. Similarly, Puig et al. [52] showed the efficacy of different synthetic antimicrobial peptides against $S$. vesicarium in detached "Conference" pear leaves. The authors concluded that prophylactic application of these antimicrobial peptides did not reduce the infection, but curative application did. In agreement with these results, propolis seems to be more efficient in reducing the disease incidence when applied after pathogen inoculation (curative assay) than when applied before pathogen inoculation (prophylactic assay). This result is particularly interesting as scarce fungicides with post-infection action are available for use on pears [52].

\section{Conclusions}

Under the conditions of the current study, propolis extracts were able to efficiently reduce S. vesicarium growth in vitro. Moreover, propolis extracts were also effective in reducing in vivo S. vesicarium disease incidence and severity in "Rocha" pears. Thus, results obtained suggest that propolis extracts have potential to be applied as part of an integrated approach, in conjunction with other natural products or with synthetic fungicides, in the control of brown spot of pear. The utilization of propolis as a natural preservative may help to improve disease control and to decrease the use of synthetic fungicides minimizing the risks associated with these products.

Author Contributions: M.L., M.P.D., C.S., and M.G. conceived and designed the experiments. E.D. isolated and identified the fungus. M.L., E.M.M., M.S., P.V., and A.S.C. performed the experiments and analyzed the data. M.L., M.P.D., and C.S. wrote the paper with contributions from B.M. and M.G., M.P.D. and C.S. supervised the execution of analyses and revised the data. All authors have read and agreed to the published version of the manuscript.

Funding: This work was funded by PRODER (Programme for the Rural Development of Mainland Portugal), Medida 4.1, under the project ProFruta (PA54101, PA54102, and PA54103). This work was also supported by FCT—Fundação para a Ciência e Tecnologia within the R\&D Units Project Scope: UIDB/04077/2020.

Conflicts of Interest: The authors declare no conflict of interest. The funders had no role in the design of the study, in the collection, analyses, or interpretation of data, in the writing of the manuscript, or in the decision to publish the results.

\section{References}

1. Diogo, E.; Sánchez, C.; Leão, M.; de Sousa, R. A Estenfiliose da Pereira Rocha em Portugal. Rev. Técnico-Cient. Agríc. 2017, 24, 46-48.

2. Llorente, I.; Montesinos, E. Brown Spot of Pear: An emerging disease of economic importance Europe. Plant Dis. 2006, 90, 1368-1375. [CrossRef] 
3. Rossi, V.; Pattori, E. Inoculum reduction of Stemphylium vesicarium, the causal agent of brown spot of pear, through application of Trichoderma-based products. Biol. Control 2009, 49, 52-57. [CrossRef]

4. Puig, M.; Moragrega, C.; Ruz, L.; Calderón, C.E.; Cazorla, F.M.; Montesinos, E.; Llorente, I. Interaction of antifungal peptide BP15 with Stemphylium vesicarium, the causal agent of brown spot of pear. Fungal Biol. 2016, 120, 61-71. [CrossRef]

5. Moragrega, C.; Puig, M.; Ruz, L.; Montesinos, E.; Llorente, I. Epidemiological features and trends of brown spot of pear disease based on the diversity of pathogen populations and climate change effects. Phytopathology 2018, 108, 223-233. [CrossRef] [PubMed]

6. Puig, M.; Moragrega, C.; Ruz, L.; Montesinos, E.; Llorente, I. Controlling brown spot of pear by a synthetic antimicrobial peptide under field conditions. Plant Dis. 2015, 99, 1816-1822. [CrossRef] [PubMed]

7. Cappai, F.; De Franceschi, P.; Ciriani, A.; Collina, M.; Dondini, L. QTLs for susceptibility to Stemphylium vesicarium in pear. Mol. Breed. 2018, 38, 24. [CrossRef]

8. Llorente, I.; Moragrega, C.; Ruz, L.; Montesinos, E. An update on control of brown spot of pear. Trees 2012, 6, 239-245. [CrossRef] [PubMed]

9. Bankova, V.; de Castro, S.L.; Marcucci, M.C. Propolis: Recent advances in chemistry and plant origin. Apidologie 2000, 31, 3-15. [CrossRef]

10. Falcão, S.I.; Freire, C.; Figueiredo, A.C.; Boas, M.V. The volatile composition of Portuguese propolis towards its origin discrimination. Rec. Nat. Prod. 2016, 10, 176.

11. Marcucci, M.C. Propolis: Chemical composition, biological properties and therapeutic activity. Apidologie 1995, 26, 83-99. [CrossRef]

12. Bankova, V. Chemical diversity of propolis and the problem of standardization. J. Ethnopharmacol. 2005, 100, 114-117. [CrossRef] [PubMed]

13. Miguel, M.G.; Nunes, S.; Dandlen, S.A.; Cavaco, A.M.; Antunes, M.D. Phenols and antioxidant activity of hydro-alcoholic extracts of propolis from Algarve, South of Portugal. Food Chem. Toxicol. 2010, 48, 3418-3423. [CrossRef] [PubMed]

14. Sforcin, J.M.; Bankova, V. Propolis: Is there a potential for the development of new drugs? J. Ethnopharmacol. 2011, 133, 253-260. [CrossRef]

15. Banskota, A.H.; Tezuka, Y.; Kadota, S. Recent progress in pharmacological research of propolis. Phytother. Res. 2001, 15, 561-571. [CrossRef]

16. Viuda-Martos, M.; Ruiz-Navajas, Y.; Fernández-López, J.; Pérez-Alvarez, J.A. Functional properties of honey, propolis, and royal jelly. J. Food Sci. 2008, 73, 117-125. [CrossRef]

17. Meneses, E.A.; Durango, D.L.; Garcia, C.M. Antifungal activity against postharvest fungi by extracts from Colombian propolis. Quím. Nova 2009, 32, 2011-2017. [CrossRef]

18. Boufadi, Y.M.; Soubhye, J.; Jean, N. Antimicrobial effects of six Algerian propolis extracts. Int. J. Food Sci. Technol. 2016, 51, 2613-2620. [CrossRef]

19. Yang, S.; Peng, L.; Cheng, Y.; Chen, F.; Pan, S. Control of citrus green and blue molds by Chinese propolis. Food Sci. Biotechnol. 2010, 19, 1303-1308. [CrossRef]

20. Soylu, E.M.; Özdemir, A.E.; Ertürk, E.; Şahinler, N. Antifungal activity of propolis against Penicillium Digitatum, causal agent of green mold of citrus fruits. In Proceedings of the First European Conference of Apidology 'EurBee', Udine, Italy, 19-23 September 2004.

21. Soylu, E.M.; Özdemir, A.E.; Ertürk, E.; Şahinler, N.; Soylu, S. Chemical composition and antifungal activity of propolis against Penicillium digitatum. Asian J. Chem. 2008, 20, 4823-4830.

22. Sánchez, C.; Duarte, P.; Vasilenko, P.; Santos, M.; Loebler, M.; Cruz, A.S.; Gonçalves, M. Potential application of Portuguese propolis to control blue mould disease in 'Rocha' pear. Acta Hortic. 2016, 1144, 359-364. [CrossRef]

23. Loebler, M.; Sánchez, C.; Santos, M.; Vasilenko, P.; Duarte, M.P.; Cruz, A.; Gonçalves, M. Aplicação de extratos de própolis para conservação pós-colheita de morangos. Vida Rural. 2018, 1837, 38-40.

24. Sánchez, C.; Loebler, M.; Santos, M.; Vasilenko, P.; Cruz, A.S.; Duarte, M.P.; Gonçalves, M. Aplicación de compuestos bioactivos para conservación postcosecha de fresas. Rev. Frutic. 2018, 61, 56-65.

25. Bankova, V.; Popova, M.; Trusheva, B. New emerging fields of application of propolis. Maced. J. Chem. Chem. Eng. 2016, 35, 1-11. [CrossRef]

26. Koşar, M.; Göger, F.; Başer, K.H.C. In vitro antioxidant properties and phenolic composition of Salvia virgata Jacq. from Turkey. J. Agric. Food Chem. 2008, 56, 2369-2374. [CrossRef] 
27. Lima, K.; Silva, O.; Figueira, M.E.; Pires, C.; Cruz, D.; Gomes, S.; Maurício, E.M.; Duarte, M.P. Influence of the in vitro gastrointestinal digestion on the antioxidant activity of Artemisia gorgonum Webb and Hyptis pectinata (L.) Poit. infusions from Cape Verde. Food Res. Int. 2019, 115, 150-159. [CrossRef]

28. Kedare, S.B.; Singh, R.P. Genesis and development of DPPH method of antioxidant assay. J. Food Sci. Technol. 2011, 48, 412-422. [CrossRef]

29. Jug, M.; Končić, M.Z.; Kosalec, I. Modulation of antioxidant, chelating and antimicrobial activity of poplar chemo-type propolis by extraction procures. LWT-Food Sci. Technol. 2014, 57, 530-537. [CrossRef]

30. Moreira, L.; Dias, L.G.; Pereira, J.A.; Estevinho, L. Antioxidant properties, total phenols and pollen analysis of propolis samples from Portugal. Food Chem. Toxicol. 2008, 46, 3482-3485. [CrossRef]

31. Silva, J.C.; Rodrigues, S.; Feás, X.; Estevinho, L.M. Antimicrobial activity, phenolic profile and role in the inflammation of propolis. Food Chem. Toxicol. 2012, 50, 1790-1795. [CrossRef]

32. Dias, L.G.; Pereira, A.P.; Estevinho, L.M. Comparative study of different Portuguese samples of propolis: Pollinic, sensorial, physicochemical, microbiological characterization and antibacterial activity. Food Chem. Toxicol. 2012, 50, 4246-4253. [CrossRef] [PubMed]

33. da Silva, J.F.M.; de Souza, M.C.; Matta, S.R.; de Andrade, M.R.; Vidal, F.V.N. Correlation analysis between phenolic levels of Brazilian propolis extracts and their antimicrobial and antioxidant activities. Food Chem. 2006, 99, 431-435. [CrossRef]

34. Chaillou, L.L.; Nazareno, M.A. Bioactivity of propolis from Santiago del Estero, Argentina, related to their chemical composition. LWT-Food Sci. Technol. 2009, 42, 1422-1427. [CrossRef]

35. Falcão, S.I.; Tomás, A.; Vale, N.; Gomes, P.; Freire, C.; Vilas-Boas, M. Phenolic quantification and botanical origin of Portuguese propolis. Ind. Crop. Prod. 2013, 49, 805-812. [CrossRef]

36. Pobiega, K.; Kraśniewska, K.; Derewiaka, D.; Gniewosz, M. Comparison of the antimicrobial activity of propolis extracts obtained by means of various extraction methods. J. Food Sci. Technol. 2019, 56, 5386-5395. [CrossRef]

37. de Lima, G.G.; de Souza, R.O.; Bozzi, A.D.; Poplawska, M.A.; Devine, D.M.; Nugent, M.J. Extraction method plays critical role in antibacterial activity of propolis-loaded hydrogels. J. Pharm. Sci. 2016, 105, 1248-1257. [CrossRef]

38. Silici, S.; Koc, N.A.; Ayangil, D.; Canaya, S. Antifungal activities of propolis collected by different races of honeybees against yeasts isolated from patients with superficial mycoses. J. Pharmacol. Sci. 2005, 99, 39-44. [CrossRef]

39. Najafi, M.F.; Vahedy, F.; Seyyedin, M.; Jomehzadeh, H.R.; Bozary, K. Effect of the water extracts of propolis on stimulation and inhibition of different cells. Cytotechnology 2007, 54, 49-56. [CrossRef]

40. Campana, R.; Patrone, V.; Franzini, I.T.; Diamantini, G.; Vittoria, E.; Baffone, W. Antimicrobial activity of two propolis samples against human Campylobacter jejuni. J. Med. Food 2009, 12, 1050-1056. [CrossRef]

41. Falcão, S.I.; Vale, N.; Cos, P.; Gomes, P.; Freire, C.; Maes, L.; Vilas-Boas, M. In vitro evaluation of Portuguese propolis and floral sources for antiprotozoal, antibacterial and antifungal activity. Phytother. Res. 2014, 28, 437-443. [CrossRef]

42. Yang, S.Z.; Peng, L.T.; Su, X.J.; Chen, F.; Cheng, Y.J.; Fan, G.; Pan, S.Y. Bioassay-guided isolation and identification of antifungal components from propolis against Penicillium italicum. Food Chem. 2011, 127, 210-215. [CrossRef]

43. Cushnie, T.P.T.; Lamb, A.J. Antimicrobial activity of flavonoids. Int. J. Antimicrob. Agents 2005, 26, 343-356. [CrossRef] [PubMed]

44. Teodoro, G.R.; Ellepola, K.; Seneviratne, C.J.; Koga-Ito, C.Y. Potential use of phenolic acids as anti-Candida agents: A review. Front. Microbiol. 2015, 6, 1420. [CrossRef] [PubMed]

45. Peng, L.; Yang, S.; Cheng, Y.J.; Chen, F.; Pan, S.; Fan, G. Antifungal activity and action mode of pinocembrin from propolis against Penicillium italicum. Food Sci. Biotechnol. 2012, 21, 1533-1539. [CrossRef]

46. Alberoni, G.; Cavallini, D.; Collina, M.; Brunelli, A. Characterisation of the first Stemphylium vesicarium isolates resistant to strobilurins in Italian pear orchards. Eur. J. Plant Pathol. 2010, 126, 453-457. [CrossRef]

47. Matny, O.N. Efficacy evaluation of Iraqi propolis against gray mold of stored orange caused by Penicillium digitatum. Plant Pathol. J. 2015, 14, 153-157. [CrossRef]

48. Pereira, C.S.; Guimarães, R.J.; Pozza, E.A.; da Silva, A.A. Controle da cercosporiose e da ferrugem do cafeeiro com extrato etanólico de própolis. Ceres 2015, 55, 369-376. 
49. Ali, A.; Chow, W.L.; Zahid, N.; Ong, M.K. Efficacy of propolis and cinnamon oil coating in controlling post-harvest anthracnose and quality of chilli (Capsicum annuum L.) during cold storage. Food Bioprocess Technol. 2014, 7, 2742-2748. [CrossRef]

50. Embaby, E.M.; Hazaa, M.M.; El-Dougdoug, K.H.; Monem, A.M.O.; Abd-Elgalil, M.M.; Elwan, E.E. Control Apple Fruit Decay by Using 'Ethanol Extract of Propolis'(EEP). IJAMS 2019, 4, 1-11.

51. Abdel-Hafez, S.I.; Abo-Elyousr, K.A.; Abdel-Rahim, I.R. Effectiveness of plant extracts to control purple blotch and Stemphylium blight diseases of onion (Allium cepa L.) in Assiut, Egypt. Arch. Phytopathol. Plant Prot. 2014, 47, 377-387. [CrossRef]

52. Puig, M.; Moragrega, C.; Ruz, L.; Montesinos, E.; Llorente, I. Postinfection activity of synthetic antimicrobial peptides against Stemphylium vesicarium in pear. Phytopathology 2014, 104, 1192-1200. [CrossRef] [PubMed]

53. Montesinos, E.; Llorente, I.; Moragrega, C.; Bonaterra, A.; Cervantes, J.; Vilardell, P. Desarrollo y evaluación a escala productiva de un sistema de control racional de la estemfiliosis (Stemphylium vesicarium) del peral. Frutic. Prof. 1996, 78, 96-104.

(C) 2020 by the authors. Licensee MDPI, Basel, Switzerland. This article is an open access article distributed under the terms and conditions of the Creative Commons Attribution (CC BY) license (http://creativecommons.org/licenses/by/4.0/). 